\title{
Stabilitas Minuman Isotonik Antosianin Beras Ketan Hitam dengan Senyawa Kopigmentasi Ekstrak Bunga Belimbing (Averrhoa carambola)
}

\author{
Stability of Isotonic Drink Made from Black Glutinous Rice Extract Anthocyanin with Starfruit (Averrhoa \\ carambola) Flower Extract as Copigmentation Agent
}

\author{
Akhmad Mustofa, Nanik Suhartatik* \\ Program Studi Teknologi Hasil Pertanian, \\ Fakultas Teknologi dan Industri Pangan Universitas Slamet Riyadi Surakarta, Jl. Sumpah Pemuda 18 Joglo Kadipiro \\ Surakarta 57136, Indonesia \\ *Email: n_suhartatik@yahoo.com; garadaiva@gmail.com
}

Submisi: 20 Oktober 2016; Penerimaan: 5 Februari 2018

\begin{abstract}
ABSTRAK
Antosianin merupakan komponen bioaktif dan warna dasar bahan makanan yang berwarna merah, ungu, biru hingga kehitaman. Antosianin berpotensi dikembangkan sebagai pewarna alami untuk makanan, akan tetapi pigmen ini bersifat tidak stabil. Beberapa penelitian telah dilakukan untuk meningkatkan stabilitasnya dalam sistem pangan. Tujuan dari penelitian ini adalah untuk menganalisis stabilitas antosianin dalam minuman isotonik sebagai sistem pangan dengan penambahan senyawa kopigmentasi yang berasal dari ekstrak bunga belimbing. Stabilitas minuman isotonik diuji pada beberapa suhu pemanasan dan periode penyimpanan. Minuman isotonik diformulasikan menggunakan antosianin hasil ekstraksi dari tepung beras ketan hitam. Minuman isotonik terdiri dari sukrosa, fruktosa, Na-benzoat, asam sitrat, $\mathrm{KCl}$, dan $\mathrm{K}_{2} \mathrm{PO}_{4}$ yang diatur mengandung antosianin setara dengan $25 \mathrm{mg} / \mathrm{L}$. Bahan yang ditambahkan untuk meningkatkan stabilitas antosianin pada minuman isotonik adalah ekstrak bunga maya (belimbing) 5\%. Selama penyimpanan diamati kadar fenolik, kadar antosianin, dan aktivitas antioksidan dari minuman isotonik. Hasil penelitian menunjukkan bahwa proses pemanasan menyebabkan penurunan yang signifikan dari kadar antosianin, dari semula $25 \mathrm{mg} / \mathrm{L}$ menjadi hanya $2,82 \mathrm{mg} / \mathrm{L}$ saja. Penurunan kadar antosianin terjadi juga selama penyimpanan. Perlakuan suhu 50,65 , dan $70^{\circ} \mathrm{C}$ memberikan perbedaan kadar fenolik yang tidak signifikan. Begitu pula dengan kemampuannya untuk menangkap radikal DPPH (\% RSA DPPH, radical scavenging activity 2,2diphenyl-1-picrylhydrazy). Kenaikan suhu dari 50 menjadi $70^{\circ} \mathrm{C}$, meningkatkan stabilitas antosianin, meningkatkan kadar fenolik, dan aktivitas antioksidannya. Sementara proses penyimpanan membuat kadar antosianin semakin menurun dan meningkatkan kadar fenolik serta aktivitas antioksidannya.
\end{abstract}

Kata kunci: Antosianin; antioksidan; stabilitas minuman; isotonik

\begin{abstract}
Anthocyanin is a bioactive component which give basic color of red, purple, and blue to blackish foodstuffs. So, the anthocyanin could be developed as a natural pigment in foodstuffs, but it is unstable. Several studies have been conducted to improve its stability in the food system. The purpose of this study was to analyze the stability of anthocyanin in isotonic beverages as food system with the addition of copigmentation compound derived from star fruit flower extract. The stability of the isotonic beverage was tested at some heating temperatures and storage periods. Isotonic drink were formulated using anthocyanin extracted from glutinous rice flour. Isotonic beverages consist of sucrose, fructose, sodium benzoate, citric acid, $\mathrm{KCl}$, and $\mathrm{K}_{2} \mathrm{PO}_{4}$ which were regulated containing anthocyanin equivalent to $25 \mathrm{mg} / \mathrm{L}$. Added ingredients to increase the stability of anthocyanin in isotonic drinks was $5 \%$ star-fruit flower extract. During storage, the phenolic content, anthocyanin, and antioxidant activity of isotonic beverages were observed. The results showed that heating process declined the anthocyanin content significantly, from $25 \mathrm{mg} / \mathrm{L}$ to $2.82 \mathrm{mg} / \mathrm{L}$. Decreased level of anthocyanin also occurred during storage. Heating at 50, 65, and 70 ${ }^{\circ} \mathrm{C}$ gave no significant difference of phenol content. Similar to its ability to capture DPPH radicals (\% RSA DPPH, radical scavenging activity 2.2-diphenyl-1-picrylhydrazyl). Increasing the temperature from 50 to $70{ }^{\circ} \mathrm{C}$ would increase the stability of anthocyanin, total phenolic, and also the antioxidant activity. Meanwhile, storage would decrease the anthocyanin content but increase the phenolic content and the antioxidant activity.
\end{abstract}


Keywords: Anthocyanin; antioxidant; beverage stability; isotonic

\section{PENDAHULUAN}

Antosianin merupakan komponen bioaktif dan warna dasar bahan makanan yang berwarna merah, ungu, biru hingga kehitaman. Warna alami yang dibawa antosianin berpotensi untuk dikembangkan sebagai pewarna alami untuk makanan. Konsumsi antosianin dalam diet terbukti mampu memberikan efek perlindungan terhadap penyakit kardiovaskuler, diabetes militus, antioksidan, anti inflammasi, dan antikanker (Ghiselli dkk., 1998; Matsui dkk., 2002; Oki dkk., 2002; Bagchi dkk., 2004; Kano dkk., 2005; Wang dan Stoner, 2009). Sebagai antitumor dan antikanker, antosianin terbukti mampu menekan pertumbuhan sel HCT-15 (Kamei dkk., 1998) dan HL-60 (Katsube dkk., 2003).

Stabilitas antosianin relatif rendah selama proses pemanasan dan penyimpanan. Antosianin mudah mengalami kerusakan dengan adanya pemanasan, cahaya, pH, keberadaan oksigen, dan lain-lain. Beberapa penelitian membuktikan bahwa antosianin pada beberapa produk pangan mengalami kerusakan karena faktor-faktor tersebut, misalnya pada ekstrak antosianin dari jus wortel hitam (Ersus dan Yurdagel, 2007); ekstrak kasar dari bunga Ranunculus asiaticus (Amr dan Al-Tamimi, 2007); jus acai kering beku (Renata dkk., 2009); dan minuman isotonik menggunakan beras ketan hitam (Suhartatik dkk., 2013). Antosianin juga telah dikembangkan menjadi pewarna alami dengan senyawa pelindung yang stabil terhadap pemanasan, yaitu manitol (Elderidge dkk., 2014).

Beberapa bahan penstabil sering digunakan untuk meningkatkan stabilitas antosianin pada bahan pangan. Bahan yang sering ditambahkan diantaranya adalah maltodekstrin, gum arab, dan tepung tapioka (Renata dkk., 2009), pigmen lain seperti asam sinapat, asam kafeat, asam ferulat, dan rosemary (Sari dkk., 2012), atau menggunakan pigmen yang berasal dari bahan pangan lain (Kirca dkk., 2006). Penelitian ini menggunakan komponen warna pada bahan pangan lain untuk meningkatkan stabilitas warna antosianin beras ketan hitam. Istilah yang sering digunakan adalah senyawa kopigmentasi. Menurut Castenada dkk. (2009), kopigmentasi dapat terjadi melalui beberapa interaksi, diantaranya self-association; intramolecullar copigmentation, metal complexation, dan intermolecular copigmentation. Senyawa kopigmentasi juga dapat ditambahkan berupa pigmen dari bahan lain yang berupa flavonoid, alkaloid, asam amino, asam organik, nukleotida, polisakarida, atau antosianin jenis lain.

Sejauh ini mekanisme kopigmentasi belum dapat dipahami secara jelas. Namun ada dugaan bahwa senyawa kopigmen akan melindungi kromofor $\mathrm{C}-2$ pada cincin piranik dari serangan nukleofil dari air yang akan menyebabkan hilangnya warna (Dangles dan Brouillard,
1992; de Freitas dan Mateus, 2006). Di samping itu Ferreira da Silva dkk. (2005) menjelaskan bahwa mekanisme kopigmentasi antara antosianin dengan polifenol hanyalah fenomena transfer elektron biasa. Dalam hal ini, antosianin akan berperan sebagai penerima elektron sedangkan senyawa kopigmen berperan sebagai elektron donor. Apabila mekanisme ini yang berperan, maka harus dicari senyawa kopigmen yang mempunyai potensial ionisasi yang lebih rendah.

Pigmen yang digunakan sebagai senyawa kopigmentasi adalah senyawa pigmen pada ekstrak bunga belimbing atau biasa disebut dengan bunga maya. Bunga maya sering digunakan sebagai obat alami untuk penurun demam, antikelmintik, subkalorisme, dan pengobatan malaria. Bunga maya digunakan sebagai obat tradisional dengan cara direbus atau disiram langsung dengan air mendidih. Bunga belimbing juga sering ditambahkan ke dalam salad buah di Negara India (Payal dkk., 2012). Penelitian ini bertujuan untuk menganalisis pengaruh penambahan senyawa penstabil berupa flavonoid pada bahan pangan lain, seperti bunga maya, menggunakan minuman isotonik sebagai model sistem

\section{METODE PENELITIAN}

\section{Bahan dan Alat}

Beras ketan hitam yang digunakan dalam penelitian ini diperoleh dari pasar tradisional di sekitar Solo. Medium yang digunakan adalah media pertumbuhan mikroorganisme MRS Broth (Merck Ltd.), ekstrak yeast (Oxoid Ltd.), agar, peptone (Difco), glukosa, akuades, dan $\mathrm{CaCO}_{3}$. Bahan kimia yang digunakan semua merupakan standar analisis (p.a). Alat yang digunakan adalah autoklaf (HiClave HVE-25, Hirayama), vortex (Thermoline, Tipe 37600), transferring pipette (Soccorex), laminar flow (Gelman Science, tipe BH/20), oven (Heraus, tipe UT5042EK), spektrofotometer UV (Shimadzu, UV-1601), evaporator vakum (IKA, tipe HB 10), dan peralatan gelas lain.

\section{Pembuatan Ekstrak Antosianin Beras Ketan Hitam}

Beras ketan hitam digiling dan diayak dengan ukuran 40 mesh. Ekstraksi dilakukan dengan cara maserasi dalam larutan asam sitrat 1:3 selama 24 jam pada ruang gelap suhu $4^{\circ} \mathrm{C}$. Selama proses maserasi, dilakukan pengadukan. Supernatan yang didapat kemudian disaring menggunakan kertas saring. Sebelum digunakan lebih lanjut, ekstrak antosianin berasketan hitam ini disimpan pada botol tidak tembus cahaya dan suhu beku. 


\section{Minuman Isotonik dan Penambahan Senyawa Penstabil}

Komposisi minuman isotonik per 1 liternya adalah 55 g sukrosa; 5,5 g fruktosa, 0,15 $\mathrm{Na}$ benzoat, 3,0 asam sitrat, 0,14 $\mathrm{g} \mathrm{KCl}$, dan 0,4 $\mathrm{g} \mathrm{K}_{2} \mathrm{PO}_{4}$ (Rosso dan Mercadante, 2007). Minuman isotonik diatur supaya mengandung antosianin setara dengan $25 \mathrm{mg} / \mathrm{L}$. Bahan yang ditambahkan untuk meningkatkan stabilitas antosianin pada minuman isotonik adalah ekstrak bunga maya 5\%.

\section{Pelaksanaan penelitian}

Stabilitas antosianin pada minuman isotonik dengan penambahan senyawa ko-pigmentasi dipantau setiap minggu selama 4 minggu penyimpanan. Sebelum penyimpanan, minuman isotonik dipanaskan pada suhu yang berbeda untuk melihat pengaruh pemanasan terhadap stabilitasnya. Pemanasan dilakukan pada suhu 50, 65, dan $70{ }^{\circ} \mathrm{C}$ selama 5 menit. Penyimpanan dilakukan pada suhu kamar dengan paparan siang dan malam. Analisis stabilitas warna antosianin pada minuman isotonik dipantau dengan cara melakukan analisis total fenolik (Singleton dan Rossi (1965), total antosianin (Giusti dan Worstald, 2001), dan DPPH (Xu dan Chang, 2007 dalam Pujimulyani dkk., 2010).

\section{Analisis Total Fenolik}

Analisis total fenolik menggunakan metoda Volden dkk. (2008) dalam Pujimulyani dkk. (2010) yang dimodifikasi sesuai dengan jenis sampelnya, yaitu dilakukan dengan cara menambahkan $200 \mu \mathrm{L}$ sampel

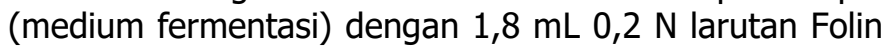
Ciocalteau dan $1,8 \mathrm{~mL} 60 \mathrm{~g} / \mathrm{L} \mathrm{Na}_{2} \mathrm{CO}_{3}$ pada suhu kamar. Sebelum ditera pada $\lambda 760 \mathrm{~nm}$, campuran divorteks terlebih dahulu dan didiamkan pada suhu kamar selama 1,5 jam. Total fenolik dinyatakan dalam mg asam galat/100 $\mathrm{mL}$ sampel dengan menggunakan asam galat sebagai larutan standar dan perlakuan analisis yang sama.

\section{Analisis Total Antosianin}

Prinsip peneraan antosianin dengan metoda Giusti dan Wrostald (2001) adalah bahwa antosianin akan mengalami perubahan warna berdasarkan perubahan pH. Pada pH 1,0, antosianin berada dalam bentuk oxonium/flavilium yang mempunyai intensitas warna

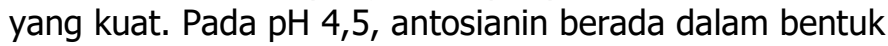
karbinol yang tidak berwarna. Analisis total antosianin ini dilakukan dengan cara membandingkan absorbansi sampel pada panjang gelombang $700 \mathrm{~nm}$ dan $512 \mathrm{~nm}$ pada $\mathrm{pH} 1$ dan $\mathrm{pH}$ 4,5.

\section{Pembuatan buffer pH 1}

$1,49 \mathrm{~g} \mathrm{KCl}$ dilarutkan dalam $100 \mathrm{~mL}$ akuadest serta $1,7 \mathrm{~mL} \mathrm{HCl}$ pekat dicampurkan ke dalam $100 \mathrm{~mL}$ akuadest. Kemudian campurkan $25 \mathrm{~mL}$ larutan $\mathrm{KCl}$ dengan $67 \mathrm{~mL}$ larutan $\mathrm{HCl}$. Selanjutnya $\mathrm{pH}$ diukur dengan $\mathrm{pH}$ meter sampai mencapai $\mathrm{pH} 1$ dengan penambahan larutan $\mathrm{HCl}$.

\section{Pembuatan buffer pH 4,5}

Sebanyak 1,64 g natrium asetat dilarutkan dalam $100 \mathrm{~mL}$ akuadest. Kemudian ditambahkan larutan $\mathrm{HCl}$ dengan hati-hati sampai mencapai pH 4,5.

\section{Peneraan menggunakan spektrofotometer}

Analisis antosianin mempergunakan metoda perbedaan $\mathrm{pH}$. Sampel ekstrak beras ketan hitam masing-masing sebanyak 0,1 mL dicampur dengan 6,4 $\mathrm{mL}$ larutan buffer $\mathrm{pH} 1$ dan $\mathrm{pH}$ 4,5. Kemudian dilakukan pengukuran absorbansi pada $\lambda 512 \mathrm{~nm}$ dan $700 \mathrm{~nm}$.

Hasil pengukuran absorbansi dimasukkan ke dalam Persamaan 1.

Kandungan antosianin $=\frac{\mathrm{A}}{\varepsilon+1} \times \mathrm{BM} \times \mathrm{DF}$

\section{Dimana:}

$$
\begin{array}{ll}
\text { A } & \left.=\left[\left(A_{\lambda 513}-\mathrm{A}_{\lambda 700}\right) \mathrm{pH} 1-\left(\mathrm{A}_{\lambda 513}-\mathrm{A}_{\lambda 700}\right) \mathrm{pH} 4,5\right)\right] \\
\mathrm{BM} & =\text { berat molekul }(449,2) \\
\text { DF } & =\text { Dilution Factor } \\
\varepsilon & =\text { koefisien ekstingsi molar sianidin 3-glikosida } \\
& =26.900
\end{array}
$$

\section{Analisis Aktivitas Antioksidan}

Aktivitas antioksidan (DPPH) ditentukan dengan mencampur 0,2 $\mathrm{mL}$ sampel (medium fermentasi) dengan 3,8 $\mathrm{mL}$ larutan $1 \mathrm{mM}$ DPPH (dalam metanol) dan diinkubasi selama 1 jam pada suhu kamar serta kondisi gelap. Peneraan dilakukan pada panjang gelombang $515 \mathrm{~nm}$. Blanko dibuat dengan menggantikan sampel dengan akuades pada volume yang sama. Persentase penangkapan radikal bebas dinyatakan dalam persentase penghambatan radikal bebas DPPH (Persamaan 2).

$\%$ RSA DPPH $=\frac{\text { Absorbansi DPPH-Absorbansi sampel }}{\text { Absorbansi DPPH }} \times 100$

\section{Analisis Data}

Data hasil analisis diolah dengan ANOVA (two ways anova) untuk uji beda nyata. Apabila terdapat beda nyata, maka uji dilanjutkan dengan Duncan Multiple Range Test pada taraf signifikansi 5\%. Analisis dilakukan dengan software SPSS 19.1 dari USA.

\section{HASIL DAN PEMBAHASAN}

Bunga belimbing yang direbus, biasanya digunakan sebagai obat alami untuk penurun demam, antihelmintik, subkalorisme, dan pengobatan malaria. Dalam penelitian ini, minuman isotonik yang diformulasikan menggunakan antosianin dari beras ketan hitam distabilkan warnanya menggunakan pewarna alami antosianin dari bunga belimbing. 
Komponen antosianin yang terdapat pada bunga maya belum diteliti. Hasil peneraan kadar antosianin setelah proses pemanasan dan penyimpanan pada beberapa konsenstrasi ekstrak antosianin bunga maya dapat dilihat pada Tabel 1. Kadar antosianin minuman isotonik berbasis antosianin dengan penambahan senyawa kopigmentasi ekstrak bunga maya menunjukkan adanya penurunan yang signifikan setelah disimpan selama 1 minggu, baik untuk minuman isotonik yang dipasteurisasi pada suhu 50 atau $65^{\circ} \mathrm{C}$ maupun suhu 70 ${ }^{\circ} \mathrm{C}$. Proses pemanasan juga secara signifikan menurunkan kadar antosianin dari $25 \mathrm{mg} / \mathrm{L}$ menjadi hanya 2,82 $\mathrm{mg} / \mathrm{L}$ saja. Walaupun demikian kenaikan suhu dari 50 menjadi $70{ }^{\circ} \mathrm{C}$ menunjukkan kenaikan kadar antosianin, walaupun tidak terlalu signifikan, namun dapat dikatakan bahwa suhu $70{ }^{\circ} \mathrm{C}$ memberikan dampak stabilitas yang lebih baik dari pada suhu di bawahnya. Perbedaan ekstrak bunga maya yang diberikan pada minuman isotonik ternyata memberikan dampak terhadap kadar antosianin pada minuman isotonik, walaupun kenaikan ini tidaklah terlalu signifikan. Hasil ini berbeda dengan penelitian yang dihasilkan oleh Dharmawan (2009) yang menyatakan bahwa semakin tinggi suhu pemanasan semakin tinggi pula waktu paruh pewarna alaminya. Dharmawan (2009) meninjau efek penambahan senyawa kopigmentasi Brazilien dari kayu secang dalam upaya meningkatkan stabilitas antosianin dari bunga rosella (Hisbiscus sabdariffa L.). Adapun suhu yang diuji meliputi 40, 50, 60, 70, dan $80^{\circ} \mathrm{C}$. Namun dari hasil penelitian tersebut dapat dibuktikan bahwa penambahan ekstrak kayu secang dapat meningkatkan stabilitas warna antosianin bunga rosella dibandingkan dengan minuman isotonik yang tidak ditambah dengan kopigmen. Sari dkk. (2005) menyatakan bahwa antosianin ekstrak jambolan stabil pada suhu 40 dan 60 ${ }^{\circ} \mathrm{C}$ namun tidak stabil pada suhu 80 dan $100{ }^{\circ} \mathrm{C}$. Stabilitas warna dapat turun hingga $80 \%$ jika dipanaskan pada suhu ini.

Kadar fenolik minuman isotonik antosianin dengan senyawa kopigmentasi ekstrak bunga maya mengalami kenaikan selama proses penyimpanan (Tabel 2). Patras dkk. (2010) menyampaikan bahwa hasil degradasi termal antosianin akan menghasilkan senyawa fenolik lain, seperti asam protokatekoat (asam 4hidroksibensoat), ploroglusinaldehida, dan sianidin. Dengan demikian hasil degradasi antosianin akan menyebabkan peningkatan kadar fenoliknya. Kadar fenolik minuman isotonik tertinggi terdapat pada sampel dengan penambahan ekstrak bunga maya sebanyak $15 \%$ dan pemanasan $70{ }^{\circ} \mathrm{C}$ serta penyimpanan selama 3 minggu. Hasil yang sama juga dilaporkan oleh Kirca dkk. (2006). Dalam pengujian jus wortel hitam, adanya pemanasan dan penyimpanan akan semakin meningkatkan laju degradasi antosianin. Penyimpanan suhu dingin akan memperlambat laju degradasi antosianin pada jus wortel hitam. Selain itu juga disampaikan bahwa total solid akan berpengaruh pada laju degradasi antosianin.

Tabel 1. Kadar antosianin (mg/L) minuman isotonik dengan senyawa kopigmentasi ekstrak bunga maya (belimbing)

\begin{tabular}{|c|c|c|c|c|}
\hline \multirow{2}{*}{$\begin{array}{c}\text { Kadar } \\
\text { ekstrak } \\
\text { maya }\end{array}$} & \multicolumn{3}{|c|}{ Suhu pemanasan $\left({ }^{\circ} \mathrm{C}\right)$} & \multirow{2}{*}{$\begin{array}{c}\text { Lama } \\
\text { simpan } \\
\text { (minggu) }\end{array}$} \\
\hline & 50 & 65 & 70 & \\
\hline \multirow{4}{*}{$5 \%$} & $2,61_{a b}$ & $2,66_{a b}$ & $2,34 a b$ & 0 \\
\hline & $1,74_{a b}$ & $1,85_{a b}$ & $1,80_{a b}$ & 1 \\
\hline & $1,47 a$ & $1,74_{a b}$ & $1,85_{a b}$ & 2 \\
\hline & $1,69_{a b}$ & $1,69_{a b}$ & $1,69_{a b}$ & 3 \\
\hline \multirow{4}{*}{$10 \%$} & $2,77 a b$ & $2,99 b$ & $2,56 a b$ & 0 \\
\hline & $1,69_{\mathrm{ab}}$ & $1,85_{a b}$ & $1,96_{a b}$ & 1 \\
\hline & $1,96_{a b}$ & $1,79_{\mathrm{ab}}$ & $1,80_{a b}$ & 2 \\
\hline & $1,47 a$ & $1,63_{\mathrm{ab}}$ & $1,74_{a b}$ & 3 \\
\hline \multirow{4}{*}{$15 \%$} & $2,66_{a b}$ & $1,85_{a b}$ & $2,82_{a b}$ & 0 \\
\hline & $1,47 a$ & $1,96 a b$ & $2,17 \mathrm{ab}$ & 1 \\
\hline & $1,69_{\mathrm{ab}}$ & $2,06_{a b}$ & $1,95 \mathrm{ab}$ & 2 \\
\hline & $1,63_{a b}$ & $1,85_{a b}$ & $1,69 a b$ & 3 \\
\hline
\end{tabular}

Keterangan: angka yang diikuti notasi berbeda pada kolom yang sama menunjukkan beda nyata pada taraf signifikansi $5 \%$

Baik antosianin maupun senyawa fenolik mempunyai kemampuan sebagai antioksidan. Adanya degradasi antosianin menjadi senyawa fenolik akan merubah aktivitasnya sebagai antioksidan. Hasil menunjukkan bahwa aktivitas antioksidan minuman isotonik antosianin beras ketan hitam dengan penambahan senyawa kopigmentasi ekstrak bunga maya cenderung mengalami kenaikan selama proses penyimpanan (Tabel 3). Pemanasan pada suhu 50, 65, dan $70{ }^{\circ} \mathrm{C}$ menghasilkan aktivitas antioksidan yang tidak berbeda nyata pada taraf signifikansi $5 \%$. Semakin lama waktu penyimpanan, semakin tinggi pula aktivitas antioksidannya. Penyimpanan selama 3 minggu dan ekstrak bunga maya sebanyak $15 \%$ menghasilkan aktivitas antioksidan yang paling tinggi. Hasil yang sama juga ditunjukkan oleh Kirca dkk. (2006), yaitu suhu pemanasan akan menyebabkan degradasi antosianin pada jus wortel hitam. Demikian pula dengan lama waktu penyimpanan, akan menyebabkan peningkatan laju degradasi antosianin. Hanya saja dalam penelitian tersebut tidak dilakukan pengujian terhadap aktivitas antioksidannya. Fang dkk. (2008) menyatakan bahwa ada hubungan positif antara aktivitas antioksidan dengan kadar total fenolik pada proses pembuatan acar mustard. Dalam penelitian tersebut disebutkan bahwa aktivitas antioksidan akan semakin meningkat dengan semakin meningkatnya total fenolik atau total asam fenolat.

Hasil penelitian ini terlihat bahwa penggunaan bunga maya dengan variasi 5,10 , dan $15 \%$ memberikan pengaruh signifikan terhadap peningkatan kadar fenolik maupun aktivitas antioksidan minuman isotonik. 
Tabel 2. Kadar fenolik minuman isotonik dengan senyawa kopigmentasi ekstrak bunga maya

\begin{tabular}{|c|c|c|c|c|}
\hline \multirow{2}{*}{$\begin{array}{c}\text { Kadar } \\
\text { Ekstrak } \\
\text { Maya }\end{array}$} & \multicolumn{3}{|c|}{$\begin{array}{c}\text { Kadar Fenol }(\mathrm{mg} / \mathrm{ml}) \text { pada } \\
\text { Suhu Pemanasan }\left({ }^{\circ} \mathrm{C}\right)\end{array}$} & \multirow{2}{*}{$\begin{array}{c}\text { Lama } \\
\text { simpan } \\
\text { (Minggu) }\end{array}$} \\
\hline & 50 & 65 & 70 & \\
\hline \multirow{4}{*}{$5 \%$} & $1,38_{a}$ & $1,88_{\mathrm{abc}}$ & $2,04_{a b}$ & 0 \\
\hline & $1,62_{a}$ & $1,76_{a b}$ & $2,02 \mathrm{a}$ & 1 \\
\hline & $2,02 a$ & $2,43 c$ & $2,70_{\mathrm{bc}}$ & 2 \\
\hline & $2,46_{b}$ & $2,56 \mathrm{c}$ & $2,93 c$ & 3 \\
\hline \multirow{4}{*}{$10 \%$} & $1,57 a$ & $2,36_{b c}$ & $2,62_{a b c}$ & 0 \\
\hline & $1,70_{a}$ & $2,28_{b c}$ & $2,90_{c}$ & 1 \\
\hline & $1,98_{a b}$ & $2,67_{c}$ & $3,19_{\mathrm{cd}}$ & 2 \\
\hline & $2,38_{b c}$ & $3,00_{d}$ & $3,71_{d}$ & 3 \\
\hline \multirow{4}{*}{$15 \%$} & $2,58_{b c}$ & $2,73_{c d}$ & $2,90_{c}$ & 0 \\
\hline & $2,74_{c}$ & $2,24 a b c$ & $2,91_{c}$ & 1 \\
\hline & $3,43_{d}$ & $3,37_{d}$ & $3,69 d$ & 2 \\
\hline & $5,31_{\mathrm{e}}$ & $3,41_{d}$ & $8,36_{\mathrm{e}}$ & 3 \\
\hline
\end{tabular}

Keterangan: angka yang diikuti notasi berbeda pada kolom yang sama menunjukkan beda nyata pada taraf signifikansi $5 \%$

Tabel 3. Aktivitas antioksidan (\%RSA DPPH) minuman isotonik antosianin beras ketan hitam dengan senyawa kopigmentasi ekstrak bunga maya

\begin{tabular}{|c|c|c|c|c|}
\hline \multirow{2}{*}{$\begin{array}{c}\text { Kadar } \\
\text { Ekstrak } \\
\text { Maya }\end{array}$} & \multicolumn{3}{|c|}{ Suhu Pemanasan $\left({ }^{\circ} \mathrm{C}\right)$} & \multirow{2}{*}{$\begin{array}{c}\text { Lama } \\
\text { simpan } \\
\text { (Minggu) }\end{array}$} \\
\hline & 50 & 65 & 70 & \\
\hline \multirow{4}{*}{$5 \%$} & $49,22_{a}$ & $56,59_{a}$ & $55,58_{a}$ & 0 \\
\hline & $58,57 \mathrm{abc}$ & $64,22_{a b}$ & $65,10_{a b}$ & 1 \\
\hline & $68,56 \mathrm{abc}$ & $77,41_{a b}$ & $78,81_{\mathrm{bc}}$ & 2 \\
\hline & $78,04_{c}$ & $77,28_{a b}$ & $72,02_{a b c}$ & 3 \\
\hline \multirow{4}{*}{$10 \%$} & $51,84_{a b}$ & $57,85_{a}$ & $71,90_{\mathrm{abc}}$ & 0 \\
\hline & $58,47 \mathrm{abc}$ & $65,66_{a b}$ & $71,97 \mathrm{abc}$ & 1 \\
\hline & $69,97 \mathrm{abc}$ & $80,22_{b}$ & $80,65_{b c}$ & 2 \\
\hline & $70,59_{b c}$ & $75,21_{\mathrm{ab}}$ & $82,79_{b c}$ & 3 \\
\hline \multirow{4}{*}{$15 \%$} & $62,02_{\mathrm{abc}}$ & $62,60_{a b}$ & $72,10_{a b c}$ & 0 \\
\hline & $66,58 \mathrm{abc}$ & $67,97 \mathrm{ab}$ & $71,61_{a b c}$ & 1 \\
\hline & $70,67_{b c}$ & $81,35_{b}$ & $76,01_{\mathrm{abc}}$ & 2 \\
\hline & $77,85_{c}$ & $81,44_{b}$ & $87,00_{c}$ & 3 \\
\hline
\end{tabular}

Keterangan: angka yang diikuti notasi berbeda pada kolom yang sama menunjukkan beda nyata pada taraf signifikansi $5 \%$

Adapun faktor yang mempengaruhi keberhasilan proses kopigmentasi adalah $\mathrm{pH}$, kekuatan ionik larutan, suhu, dan ratio molar senyawa pigmen dengan kopigmentasinya (Davies dan Mazza, 1993). Namun kopigmentasi tidak selalu menghasilkan warna yang stabil dan memperbaiki pigmen asli (Salas dkk., 2004). Pada percobaan pemakaian ekstrak bunga maya sebagai senyawa kopigmentasi pada minuman isotonik antosianin ekstrak beras ketan hitam, minuman isotonik mengalami perubahan warna merah menjadi merah muda hingga penyimpanan selama 3 minggu. Secara umum dapat dikatakan bahwa ekstrak bunga maya berpotensi untuk dikembangkan sebagai senyawa kopigmentasi pada antosianin beras ketan hitam.

\section{KESIMPULAN}

Ekstrak bunga maya berpotensi untuk dikembangkan sebagai senyawa kopigmentasi pada minuman isotonik antosianin beras ketan hitam. Kadar antosianin minuman isotonik antosianin beras ketan hitam dengan senyawa kopigmentasi ekstrak bunga maya mengalami penurunan selama proses pemanasan maupun penyimpanan. Kadar antosianin menurun drastis dari $25 \mathrm{mg} / \mathrm{L}$ menjadi $2,82 \mathrm{mg} / \mathrm{L}$ selama proses pemanasan. Proses pemanasan juga memberi efek pada penurunan aktivitas antioksidan, dan total fenolik minuman isotonik antosianin. Sementara itu aktivitas antioksidan dan total fenoliknya mengalami kenaikan selama proses penyimpanan.

\section{UCAPAN TERIMA KASIH}

Penulis mengucapkan terima kasih kepada Direktorat Riset dan Pengabdian kepada Masyarakat (DRPM) Ditjen Peneltian dan Pengambangan Kemenristekdikti melalui Program Hibah Bersaing tahun 2016.

\section{DAFTAR PUSTAKA}

Amr, A., \& Al-Tamimi, E. (2007). Stability of the crude extracts of Ranunculus asiaticus anthocyanins and their use as food colorants. International Journal of Food Science and Technology, 42, 985-991. https://doi.org/10.1111/j.1365-2621.2006.01334.x.

Bagchi, D., Sen, C. K., Bagchi, M., \& Atalay, M. (2004). Antiangiogenic, antioxidant, and anticarcinogenic properties of a novel anthocyanin-rich berry extract formula. Biochemistry, 69, 75-80.

Castenada-Ovando, A., Hernandez, L. P., Hernandez, M. E. P., \& Galan-Vidal, L. A. (2009). Chemical studies of anthocyanins: A review. Food Chemistry, 113, 859-871. https://doi.org/10.1016/j.foodchem.2008.09.001.

Dangles, O., Elhabiri, M., dan Brouillard, R. (1994). Kinetic and thermodynamic investigation of the aluminiumanthocyanin complexation in aqueous solutions. Journal of Chemical Society Perkin Transactions, 12, 247- 257.

Davies, A. J., \& Mazza, G. (1993). Copigmentation of simple and acylated anthocyanins with colorless phenolic compounds. Journal of Agricultural and Food Chemistry, 41, 716-720. DOI: 10.1021/jf00029a007.

Dharmawan, I. P. G. A. (2009). Pengaruh Kopigmentasi Pewarna Alami Antosianin dari Rosela (Hisbiscus sabdariffa L) dengan Brazilien dari kayu secang (Caesalpinia sappan L) terhadap Stabilitas Warna pada Model Minuman Ringan. Skripsi. Bogor: Fakultas Teknologi Pertanian Bogor.

Eldridge, J.A., Repko, D., dan Mumper, R.J. (2014). Retention of polyphenols species in spray-dreied blackberry extract using mannitol as a thermoprotectant. Journal of Medicinal Food, 10, 1064-1069. Doi: 10.1089/jmf.2013.0177.

Ersus, S., \& Yurdagel, U. (2007). Microencapsulation of anthocyanin pigments of black carrot (Daucus carota L.) by spray dryer. Journal of Food Engineering, 80, 805-812. Doi:10.1016/j.jfoodeng.2006.07.009. 
Ferreira da Silva, P., Lima, J. C., Freitas, A. A., Shimizu, K., Mac ?anita, A. L., dan Quina, F.H. (2005). Charge-transfer complexation as a general phenomenon in the copigmentation of anthocyanins. Journal of Physical Chemistry $A, 109,7329-7338$.

de Freitas, V., \& Mateus, N. (2006). Chemical transformations of anthocyanins yielding a variety of colours (Review). Environmental Chemistry Letters, 4, 175-183. Doi: 10.1007/s10311-006-0060-3.

Ghiselli, A., Nardini, M., Baldi, A., \& Scaccini, C. (1998). Antioxidant activity of different phenolic fractions separated from an Italian red wine. Journal of Agricultural and Food Chemistry, 46, 361-367. Doi: 10.1021/jf970486b.

Giusti, M. M., \& Wrostald, R. E. (2001). Characterization and measurement of anthocyanin by UV-visible spectroscopy, In Wrostald, R.E., Acree, T.E., Dekker, E.A., Penner, M.H., Reid, D.S., Schwarrtz, S.J., Shoemaker, C.F., ... Sporns, P. (eds) (2001). Handbook of food analytical chemistry: Pigmens, colorants, flavors, texture, and bioactive food components. Hoboken, New Jersey: John Wiley Sons.

Kamei, H., Hashimoto, Y., Koide, T., Kojima, T., \& Hasegawa, M. (1998). Anti-tumor effect of methanol extracts from red and white wines. Cancer Biotherapy and Radiopharmacology, 13, 447-452. Doi: 10.1089/cbr.1998.13.447.

Kano, M., Takayanagi, T., Harada, K., Makino, K., \& Ishikawa, F. (2005). Antioxidative activity of anthocyanins from purple sweet potato, Ipomoea batatas cultivar Ayamurasaki. Biochemistry, 69, 979-988. Doi: 10.1271/bbb.69.979.

Katsube, N., Iwashita, K., Tsushida, T., Yamaki, K., \& Kobori, M. (2003). Induction of apoptosis in cancer cells by Bilberry (Vaccinium myrtillus) and the anthocyanins. J Agric Food Chem, 51, 68-75. Doi: 10.1021/jf025781x.

Kirca, A., Ozkan, M., \& Cemeroglu, B. (2006). Stability of black carrot anthocyanins in various fruit juices and nectars. Food Chemistry, 97, 598-605. Doi: 10.1016/j.foodchem.2005.05.036.

Matsui, T., Ebuchi, S., \& Kobayashi, M. (2002). Antihyperglycemic effect of diacylated anthocyanin derived from Ipomoea batatas cultivar Ayamurasaki can be achieved through the Alpha-glucosidase inhibitory action. Journal of Agricultural and Food Chemistry, 50, 7244-7248.

Oki, T., Masuda, M., Furuta, S., Nishiba, Y., Terahara, N., \& Suda, I. (2002). Involvement of anthocyanins and other phenolics compound in radical-scavenging activity of purple-fleshed sweet potato cultivars. Journal of Food Science, 675), 1752-1756. https://doi.org/10.1111/j.13652621.2002.tb08718.x.

Payal, G., Pankti, K., Manodeep, C., \& Jagadivh, K. (2012). Phytochemical and pharmacological profile of Averrhoa carambola Linn: An Overview. International Research Journal of Pharmacy, 3, 88-92.

Pujimulyani, D., Raharjo, S., Marsono, Y., \& Santoso, U. (2010). Pengaruh Blanching terhadap aktivitas antioksidan, kadar fenol, flavonoid, dan tannin terkondensasi kunir putih (Curcuma mangga Val.). Agritech, 30, 141-147.

Renata, V. T., Brabet, C., \& Hubinger, M. D. (2010). Anthocyanin stability and antioxidant activity of spray-dried acai (Euterpe oleracea mart) juice produced with different carrier agents. Food Research International, 43, 907-914.

Rosso, V. V, \& Mercadante, A. Z. (2007). Evaluation of colour and stability of anthocyanins from tropical fruits in an isotonic soft drink system. Innovative Food Science and Emerging Technologies, 8, 347-352.

Roy, M. K., Juneja, L. R., Isobe, S., \& Tsuhida, T. (2009). Steam processed broccoli (Brassica oleracea) has higher antioxidant activity in chemical and cellular assay systems. Food Chemistry, 114, 263-269. Doi: 10.1016/j.foodchem.2008.09.050.

Salas, E., Le Guerneve, C., Fulcrand, H., Poncet-Legrand, C., \& Cheynier, V. (2004). Structure determination and color properties of a new directly linked flavanol-anthocyanin dimmer. Tetrahedron Letters, 45, 8725-8729.

Sari, P., Agustina, P., Komar, M., Unus, Fauzi, M., \& Lindriati, T. (2005). Ekstraksi dan stabilitas antosianin dari kulit buah duwet (Syzygium cumini). Jurnal Teknologi dan Industri Pangan, 16, 142-150.

Sari, P., Wijaya, C. H., Sajuthi, D., \& Supratman, U. (2012). Color properties, stability, and free radical scavenging activity of jambolan (Syzygium cumini) fruit anthocyanins in a beverage model system: Natural and copigmented anthocyanins. Food Chemistry, 132, 1908-1914.

Suhartatik, N., Cahyanto, M. N., Rahardjo, S., \& Rahayu, E. S. (2013). Stabilitas Antosianin Beras Ketan Hitam selama Proses Pemanasan dan Penyimpanan. Agritech, 33, 384390. https://doi.org/10.22146/agritech.9533.

Volden, J., Borge, G. I. A., Bengtsson, G. B., Hansen, M., Thygesen, I. E., \& Wicklund, T. (2008). Effect of thermal treatment on glucosinolates and antioxidant-related parameters in red cabbage (Brassica oleracea L. Ssp capitata f. rubra). Food Chemistry, 109, 595-605. http://dx.doi.org/10.1016/j.foodchem.2008.01.010.

Wang, Li-Shu., \& Stoner, G. D. (2009). Anthocyanin and their role in cancer prevention. Cancer Letters, 269(2), 281290. Doi: $10.1016 /$ j.canlet.2008.05.020.

Xu, B. J., \& Chang, S. K. C. (2007). A comparative study on phenolic profiles and antioxidant activities of legumes affected by extraction solvent. Journal of Food Science, 72, 59-66. Doi: 10.1111/j.1750-3841.2006.00260.x. 